Como citar este artigo:

Marquezan M, Fernandes TP, May LG, Braun KO. Is sodium hexametaphosphate effective in preventing metal damage in removable dentures immersed in hypochlorite cleaner? Revista Saúde (Sta. Maria). 2018; 44(1):15.

Autor correspondente:

Mariana Marquezan

E-mail: marianamarquezan@gmail. com Telefone: ( 55 ) 9674-4678

Formação Profissional: Doutora em Ortodontia pela UFRJ, Rio de Janeiro, RJ, Brasil.

Filiação Institucional: Professora

Adjunta da UFSM

Link para o currículo

Lattes: http://lattes.cnpa

br/3239936595 | 40832

Endereço para correspondência: Rua Mal. Floriano Peixoto, 1184 , sala 409, CEP 97 105-372, Santa Maria, RS.

Data de Submissão: 24/05/2016

Data de aceite: $08 / 03 / 2018$

Conflito de Interesse: Não há conflito de interesse

\section{Is sodium hexametaphosphate effective in preventing metal damage in removable dentures immersed in hypochlorite cleaner?}

\section{O hexametafosfato de sódio é eficaz na prevenção de danos de metal em próteses removíveis imersas em produtos de limpeza de hipoclorito?}

Mariana Marquezan, Tiago Pfaff Fernandes, Liliana Gressler May, Katia Olmedo Braun

\section{RESUMO}

\section{Resumo}

O objetivo deste estudo foi determinar a citotoxicidade induzida por mini-implantes ortodônticos conforme recebidos pelo fabricante, após a exposição a fluoretos, e após a exposição ao meio bucal. Oitenta e quatro mini-implantes de fabricantes brasileiros (SIN, INP e Neodent) foram divididos em sete grupos $(n=12)$ : $\mathrm{G} 1$ - SIN como recebido do fabricante; $\mathrm{G} 2$ - SIN imerso durante quinze dias em NaF 0,05\%; G3 - SIN exposto ao meiobucal; G4 - INP como recebido do fabricante; G5 - INP imerso durante quinze dias em NaF 0,05\%; G6 - Neodent como recebido do fabricante; G7 - Neodent imerso por quinze dias em $\mathrm{NaF}$ 0,05\%. Sua citotoxicidade foi avaliada por testes de exposição direta e indireta usando a levedura $\mathrm{S}$. cerevisiae. $\mathrm{O}$ estresse oxidativo também foi avaliada por meio de teste de coloração de colônias. Os resultados mostraram não haver redução significativa da viabilidade celular sobre a exposição direta ou indireta a mini-implantes.

Descritores: Procedimentos de Ancoragem Ortodôntica. Aparelhos Ortodônticos. Saccharomyces cerevisiae.

\section{ABSTRACT}

The aim of this study was to determine the cytotoxicity induced by orthodontic miniscrews as received from manufacturer, after exposure to fluorides, and after exposure to the oral environment. Eighty-four miniscrews from Brazilian manufacturers (SIN, INP, and NEODENT) were divided into seven groups ( $n=12$ ): $G 1$ - SIN as received from manufacturer; $G 2$ - SIN immersed for fifteen days in NaF 0.05\%; G3 - SIN exposed to oral environment; G4 - INP as received from manufacturer; G5 - INP immersed for fifteen days in NaF 0.05\%; G6 - Neodent as received from manufacturer; $\mathrm{G} 7$ - Neodent immersed for fifteen days in NaF 0.05\%. Their cytotoxicity was evaluated by direct and indirect exposure tests using the wild $\mathrm{S}$. cerevisiae. Oxidative stress was also evaluated through colony color assay. The results showed non-significant reduction in cell viability on direct or indirect exposure to miniscrews.

Descriptors: Orthodontic Anchorage Procedures. Orthodontic appliances. Saccharomyces cerevisiae. 


\section{Introdução}

Miniscrews (MSs) have been widely used as orthodontic anchorage, mainly in noncompliant patients to control reciprocal tooth movement, or in patients who present a reduced number or periodontaly compromised teeth ${ }^{1,2}$.

Most MSs are made of a titanium (Ti) grade $\mathrm{V}$ alloy that is more fracture-resistant than commercially pure Ti, but has reduced corrosion-resistance, favoring the release of metal ions3. Commercially pure Ti can spontaneously form a thin impermeable surface layer of titanium oxide (TiO2) that is highly biocompatible with the human body ${ }^{4,5}$. In the Ti-6Al$4 \mathrm{~V}$ alloy, the surface oxide is composed of $\mathrm{TiO}_{2}$ with small quantities of $\mathrm{Al} 2 \mathrm{O} 3$, hydroxide groups and water ${ }^{3,6}$. With the addition of aluminum and vanadium, the oxide is less stable than that of commercially pure Ti, making it more susceptible to corrosion ${ }^{7}$

Intra-oral corrosion is known to be a complex process that depends on the composition and thermomechanical state of the alloy, as well as on the manufacturing process; surface properties; mechanical aspects and systemic state of the host3. The presence of chemicals, such as sodium fluoride-based solutions in the oral cavity can also contribute to corrosion. Sodium fluoride is known to be a potent generator of corrosion in various orthodontic appliances such as

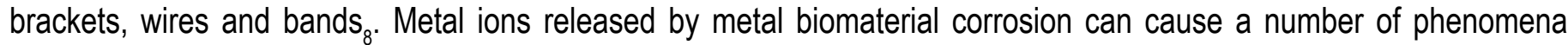
including transport, metabolization and accumulation of this material in organs, in addition to inducing disturbances varying from allergies to carcinomas6.

The aim of this study was to investigate the cytotoxicity induced by orthodontic MSs (SIN- Implant Systems, São Paulo, SP, Brazil; INP, São Paulo, SP, Brazil; and NEODENT Curitiba, PR, Brazil) as received from manufacturer, after exposure to fluorides, and after exposure to the oral environment.

\section{Metodologia}

This study was in accordance with national and international norms of research (09/04788 and 0013/09 registration number).

Eighty-four miniscrews were obtained from three different Brazilian manufacturers: SIN (SIN- Implant Systems, São Paulo, SP, Brazil, Ø1.6mm, 10mm long), INP (INP, São Paulo, SP, Brazil, $\varnothing 1.6 \mathrm{~mm}, 10 \mathrm{~mm}$ long) and NEODENT (Neodent, Curitiba, PR, Brazil, $\varnothing 1.6 \mathrm{~mm}, 9 \mathrm{~mm}$ long).

Seven groups ( $n=12$ ) were delineated: $\mathrm{G} 1$ - SIN miniscrews as received from the manufacturer; $\mathrm{G} 2$-SIN miniscrews immersed for fifteen days in NaF 0.05\% (Pharmaplus, Porto Alegre, RS, Brazil); G3 - SIN miniscrews exposed to the oral environment; G4 - INP miniscrews as received from manufacturer; G5 - INP miniscrews immersed for fifteen days in $\mathrm{NaF}$ 0.05\% (Pharmaplus, Porto Alegre, RS, Brazil); G6 - Neodent miniscrews as received from the manufacturer; G7 Neodent miniscrews immersed for fifteen days in NaF 0.05\% (Pharmaplus, Porto Alegre, RS, Brazil).

The miniscrews of Group G3 were obtained from patients undergoing orthodontic treatment for molar distalization at a private clinic. The MSs were placed between the maxillary first molar and maxillary second premolar and had an intraoral lifetime of 6 to 8 months. The MSs were removed only after total molar distalization, with no mechanical damage to the patients. After removal, the MSs were cleaned with distilled water for 10 seconds and sterilized in an autoclave (Cristofoli, Campo Mourão, PR, Brazil).

In the cytotoxicity test performed in this study, the authors used the S. strain FF18733 (mat a, ura3-52, his7-3, leu21, trp1-289, lys1-1). The cytotoxicity analysis was performed using two types of survival experiments: 1 - Direct exposure of S. cerevisiae cells to the MSs in YPD liquid medium; 2 - Indirect exposure to metals released by the MSs in commercial artificial saliva ${ }^{28}$.

For the direct exposure experiments, six miniscrews were used for each group. New inocula were cultivated from the pre-culture in $5 \mathrm{ml} \mathrm{YPD,} \mathrm{each} \mathrm{containing} \mathrm{two} \mathrm{MS} \mathrm{units} \mathrm{from} \mathrm{the} \mathrm{different} \mathrm{brands} \mathrm{tested.} \mathrm{A} \mathrm{control} \mathrm{culture} \mathrm{without} \mathrm{MS}$ was also cultivated. These cultures were incubated at $30^{\circ} \mathrm{C}$ to the exponential phase $(\sim 10-7 \mathrm{celll} / \mathrm{ml})$. Aliquots from each culture were diluted (in 0.9\% sterile saline solution) and $5 \mu$ l drops from each dilution (from 10-2 to 10-5) were plated in YPD-agar and incubated at $30^{\circ} \mathrm{C}$ for two days to allow the emergence of small colonies, thus enabling a qualitative approach. For quantitative analyses, $100 \mu \mathrm{l}$ of final dilutions were plated in YPD-agar (two plates for each dilution) at $300 \mathrm{C}$, to countcolony forming units (CFU/ml) after two days.

In experiments with exposure to saliva, six miniscrews from each group were used. The miniscrews were immersed 
in 500 $\mu$ l of artificial saliva for time intervals of twenty days (Salivan, Apsen Farmacêutica S.A., São Paulo, SP, Brazil). For each treatment, $500 \mu \mathrm{l}$ of the pre-inoculum was used. These aliquots were centrifuged (2 min to $10.000 \mathrm{rpm}$ ) and resuspended at $100 \%$ of saliva exposed to the MSs. The cells were treated for 60 minutes, diluted and plated in YPD-agar as described above, for both qualitative and quantitative analyses. A control with unexposed saliva was also cultivated.

For each test, two mini-implants were placed in contact with the yeast/ saliva, and the experiments performed in triplicate.

To evaluate the induction of respiratory loss in S. cerevisiae cells - indicating oxidative stress - the colony color assay was performed on plates from the quantitative analyses. In this test, the colonies were covered with a top layer of agar $(0.7 \%)$ containing $0.05 \%$ of the coloring salt triphenyltetrazolium-chloride (TTC). This test, by means of differential coloring of the petite colonies allows the (white) colonies to be distinguished from those that maintain their aerobic metabolism (red).

The mean and standard deviation of the colony forming units per $\mathrm{mL}(\mathrm{CFU} / \mathrm{mL})$ counts from three independent repeats of each treatment were compared with the negative control (yeast without exposure to miniscrews) to verify the occurrence of significant survival differences in a semi-log curve. As already assumed in previous published reports24,28,29, a significant difference in yeast survival is considered when there is at least one log of difference (considering the standard deviation) between treatments and negative controls in terms of CFU/ml, which is an accepted indication of cellular toxicity in S. cerevisiae,

\section{RESULTADOS:}

In the direct and indirect exposure experiments, the values of CFU/ml in experimental groups indicated some reduction in cell viability compared with the negative control groups, although these differences were not significant (lower than one log of difference in terms of CFU/ml). Results for direct and indirect experiments using SIN miniscrews are expressed in Figures 1 and 2. Similar results were observed for corroded SIN MSs as well as for other manufacturer of MSs.
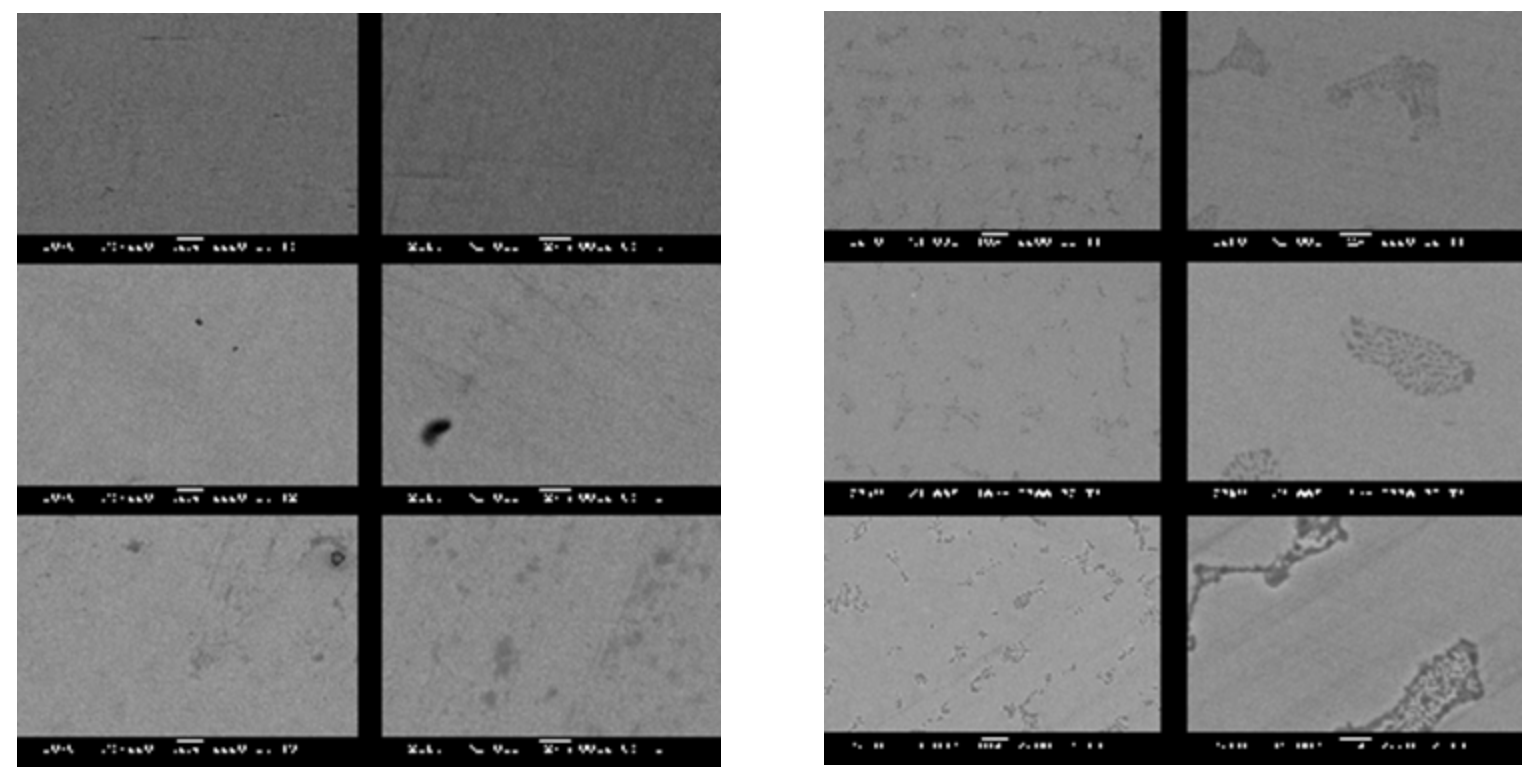

Figure 1: Sample immersed in water (G1) for 10 minutes (T1), for 20 minutes (T2), and for 60 minutes (T3) (magnification 1000X and 6000X).

Figure 2: Sample immersed in $0.5 \% \mathrm{NaOCl}(\mathrm{G} 2)$ for 10 minutes (T1), for 20 minutes (T2), and for 60 minutes (T3) (magnification 1000X and 6000X). 
The colony color assay was applied to verify the frequency of respiratory loss in S. cerevisiae cells directly or indirectly exposed to MSs. The results showed that there was apparently no mitochondrial injury induced by reactive oxygen species from MS metals, since the frequencies of petite colonies did not differ from the controls in all experiments.

\section{Discussão}

Despite reports that the release of titanium ions from Ti-6Al-4V is not associated with any pathological signs $4,9,10$, it is important to evaluate the cytotoxic effect of Ti ions, because they are released in the oral environment after miniscrew insertion11and particles of this metal may promote the proliferation of fibroblasts, an important factor in the development of a fibrous capsule surrounding the MSs. In addition, phagocytosis of these particles may cause peri-implant osteolysis ${ }^{12}$. $\mathrm{Ti}$ ions may induce a reduction in the number and activity of osteoblasts, macrophages and leukocytes 13 , hindering osteogenesis.

The results of this study suggest that the miniscrews evaluated do not present any cytotoxic effect, in agreement with previous studies ${ }^{3,14}$. Malkoç et al14 observed a lack of significant cytotoxicity when mouse osteoblasts and human gingival fibroblasts were exposed to titanium mini-implants. Moreover, an in vivo study was conducted by Morais et al ${ }^{3}$ to verify the biodegradation of orthodontic MSs (Ti6-Al4-V) and the presence of concentrations of titanium, aluminum and vanadium in rabbit organs. Small doses of all metals contained in the alloy were detected in the samples; however, the quantities were only slightly significant, thus supporting the premise that no significant cytotoxicity is generated with the use of these devices.

This study makes an important contribution to the literature with reference to evaluating the immersion of miniscrews in fluorides ( $\mathrm{NaF} 0.05 \%$ ) and their influence on cytotoxicity. This is because fluoride can increase the release of metal ions into the body15-20, and orthodontic patients are exposed to this substance when using dentifrices and mouthwashes. The results of this study demonstrated that the exposure of all the miniscrews to $\mathrm{NaF}$ for fifteen days did not induce cytotoxicity. These data are in agreement with the study of Qiu et al20, who tested the cytotoxic potential of different Ti-Bi alloys exposed to $\mathrm{NaF}$ and artificial saliva in murine fibroblasts. They observed a large number of $\mathrm{Ti}$ and $\mathrm{Bi}$ ions released in artificial saliva with NaF, but no significant deleterious effect to L929 cells and MG63 cells, similar to the effect of pure Ti.

Cytotoxicity induced by harmful agents can be assessed successfully by in vitro experiments using model microorganisms such as the yeast Saccharomyces cerevisiae21-26 - a biochemically, genetically and genomically very well described microorganism27. The use of $S$. cerevisiae as a model organism offers some advantages, since it is easy and cheap to manipulate, and provides a large amount of quantitative data from well-controlled experiments with shorttime results. Previous studies have used this yeast model to evaluate the cytotoxicity induced by different orthodontic materials However, the results should be extrapolated to clinical practice with caution. The authors suggest that further in vitro studies should be conducted with human fibroblasts, in addition toin vivo studies to evaluate the possible side effects of the metal ions released from mini-implants.

\section{Conclusão}

The miniscrews evaluated as received from manufacturer, exposed to fluorides or to the oral environment presented no cytotoxicity to $S$. cerevisiae.

\section{Referências}

1. da Cunha AC, Marquezan M, Lima I, et al. Influence of bone architecture on the primary stability of different mini-implant designs. American Journal of Orthodontics and Dentofacial Orthopedics 2015;147(1):45-51.

2. Baumgaertel S. Temporary skeletal anchorage devices: the case for miniscrews. Am J Orthod Dentofacial Orthop 2014;145(5):558-64.

3. Morais LS, Serra GG, Muller CA, et al. Titanium alloy mini-implants for orthodontic anchorage: immediate loading and metal ion release. ActaBiomater 2007;3(3):331-9.

4. Meyer U, Buhner M, Buchter A, et al. Fast element mapping of titanium wear around implants of different 
surface structures. Clin Oral Implants Res 2006;17(2):206-11.

5. Bezerra RM, de Souza PCRD, Ramires I, Bottino MA, Guastaldi AC. Corrosion resistance and microstructure of the c.p.Ti welded by laser applyed for prosthesis supported by implants. EcleticaQuimica 1999;24:11324.

6. Hanawa T. Metal ion release from metal implants. Materials Science \& Engineering C-Biomimetic and Supramolecular Systems 2004;24(6-8):745-52.

7. Marino CE, de Oliveira EM, Rocha RC, Biaggio SR. On the stability of thin-anodic-oxide films of titanium in acid phosphoric media. Corrosion Science 2001;43(8):1465-76.

8. House K, Sernetz F, Dymock D, Sandy JR, Ireland AJ. Corrosion of orthodontic appliances--should we care? Am J Orthod Dentofacial Orthop 2008;133(4):584-92.

9. Sedarat C, Harmand MF, Naji A, Nowzari H. In vitro kinetic evaluation of titanium alloy biodegradation. J Periodontal Res 2001;36(5):269-74.

10. Weingart $D$, Steinemann S, Schilli W, et al. Titanium deposition in regional lymph nodes after insertion of titanium screw implants in maxillofacial region. Int J Oral Maxillofac Surg 1994;23(6 Pt 2):450-2.

11. Blaya MG, Blaya DS, Mello P, Flores EMM, Hirakata LM. Titanium alloy miniscrews for orthodontic anchorage: an in vivo study of metal ion release. Rev Odonto Cienc 2011;26(3):209-14.

12. Garcia-Alonso MC, Saldana L, Valles G, et al. In vitro corrosion behaviour and osteoblast response of thermally oxidised Ti6Al4V alloy. Biomaterials 2003;24(1):19-26.

13. Saldana L, Barranco V, Garcia-Alonso MC, et al. Concentration-dependent effects of titanium and aluminium ions released from thermally oxidized Ti6Al4V alloy on human osteoblasts. Journal of Biomedical Materials Research Part A 2006;77A(2):220-29.

14. Malkoc S, Ozturk F, Corekci B, Bozkurt BS, Hakki SS. Real-time cell analysis of the cytotoxicity of orthodontic mini-implants on human gingival fibroblasts and mouse osteoblasts. Am J Orthod Dentofacial Orthop 2012;141(4):419-26.

15. Schiff N, Grosgogeat B, Lissac M, Dalard F. Influence of fluoride content and $\mathrm{pH}$ on the corrosion resistance of titanium and its alloys. Biomaterials 2002;23(9):1995-2002.

16. Al-MayoufAM, Al-Swayih AA, Al-Mobarak NA, Al-Jabab AS. Corrosion behavior of a new titanium alloy for dental implant applications in fluoride media. Materials Chemistry and Physics 2004;86(2-3):320-29.

17. Mabilleau G, Bourdon S, Joly-Guillou ML, et al. Influence of fluoride, hydrogen peroxide and lactic acid on the corrosion resistance of commercially pure titanium. ActaBiomater 2006;2(1):121-9.

18. Gioka C, Bourauel C, Zinelis S, et al. Titanium orthodontic brackets: structure, composition, hardness and ionic release. Dent Mater 2004;20(7):693-700.

19. Rodrigues AV, Oliveira NT, dos Santos ML, Guastaldi AC. Electrochemical behavior and corrosion resistance of Ti-15Mo alloy in naturally-aerated solutions, containing chloride and fluoride ions. J Mater Sci Mater Med 2015;26(1):5323.

20. Qiu KJ, Liu Y, Zhou FY, et al. Microstructure, mechanical properties, castability and in vitro biocompatibility of Ti-Bi alloys developed for dental applications. ActaBiomater 2015;15:254-65.

21. Perego P, Howell SB. Molecular mechanisms controlling sensitivity to toxic metal ions in yeast. ToxicolApplPharmacol 1997;147(2):312-8.

22. Avery SV. Metal toxicity in yeasts and the role of oxidative stress. Advances in Applied Microbiology, Vol 49 2001;49:111-42.

23. De Freitas J, Wintz H, Kim JH, et al. Yeast, a model organism for iron and copper metabolism studies. Biometals 2003;16(1):185-97.

24. Poletto NP, Rosado JO, Bonatto D. Evaluation of cytotoxic and cytostatic effects in Saccharomyces cerevisiae by poissoner quantitative drop test. Basic ClinPharmacolToxicol 2009;104(1):71-5.

25. Pinto AV, Deodato EL, Cardoso JS, et al. Enzymatic recognition of DNA damage induced by UVBphotosensitized titanium dioxide and biological consequences in Saccharomyces cerevisiae: evidence for oxidatively DNA damage generation. Mutat Res 2010;688(1-2):3-11.

26. Xu C, Wang J, Gao Y, et al. The anthracenedione compound bostrycin induces mitochondria-mediated 